\title{
HUBUNGAN VARIASI GEN ESTERASE DENGAN PERTUMBUHAN INDIVIDU IKAN BANDENG (Chanos cbanos)
}

\author{
Ketut Sugama*)
}

\begin{abstract}
ABSTRAK
Penelitian ini mencoba mencari hubungan antara genotip atau alel pada lokus esterase (EST) dengan pertumbuhan individu ikan bandeng. Variasi genotip atau alel pada ikan bandeng dideteksi dengan teknik elektroforesis gel tepung. Dari hasil analisis tidak terlihat adanya perbedaan laju pertumbuhan individu antara ikan yang homozigot dan heterozigot pada EST-1 lokus. Namun individu dengan genotip EST-1 AA atau alel A cendrung mempunyai berat tubuh yang lebih besar dibandingkan dengan individu dengan genotip EST-1 BB bila dipelihara pada tambak yang sama.

Dengan demikian lokus EST dapat dijadikan indikator seleksi untuk memperbaiki pertumbuhan ikan bandeng dan perlu diperhatikan untuk mempertahankan individu yang memiliki genotip EST-1 BB karena fungsinya belum diketahui dengan pasti.
\end{abstract}

ABSTRACT: Association Between Esterase Variation and Individual Weight of Milkfish. By: Ketut Sugama.

Association between esterase (EST) variation and individual weight of milkfish (Chanos chanos) were investigated. Starch gel electrophoresis was used to analyse the ester ase variation. The milkfish heterozygous or homozygous at the EST locus did not show any significant differences in individual dressed weight. The most common allele, EST-1 AA was positively associated with high weight among samples. This indicates that different EST-1 AA alleles in milkfish have different selective advantages over time, which suggests that balancing selection is important in maintaining esterase (EST) variation in milkfish and could be used as indicator for selection in improving growth of milkfish.

KEYWORDS: Esterase, weight, milkfish

\section{PENDAHULUAN}

Variasi enzim penyandi gen pada organisme perairan merupakan bahan dasar sebagai penentu sifat-sifat kuantitatif, seperti: pertumbuhan, ketahanan tehadap perubahan lingkungan atau ketahanan terhadap serangan penyakit. Dari beberapa variasi enzim yang telah dipelajari ternyata esterase atau turunan dari transferine memperlihatkan variasi yang sangat tinggi (Roed, 1987). Dari hasil penelitian terdahulu pada ikan bandeng terlihat bahwa enzim esterase memperlihatkan variasi yang sangat tinggi, baik itu dari populasi alam atau balai benih ikan bandeng (Sugama, dan Haryanti, 1995). Tingginya variasi esterase sulit untuk ditelaah, mungkin akibat dari keseimbangan alam atau faktor lain (Roed, 1986).

Zhurkevich dan Komicheva (1986) mengemukakan bahwa ada hubungan yang sangat positif antara variasi gen esterase dengan ketahanan ikan terhadap perubahan lingkungan dan penyakit. Sedangkan Sugama et al. 1992 mendapat-

") Peneliti pada Instalasi Penelitian Perikanan Pantai Gondol, Bali 
kan hubungan yang sangat positif antara esterase alel/genotip dengan pertumbuhan ikan kakap merah (Pagrus major), selanjutnya lokus esterase dijadikan indikator seleksi pertumbuhan ikan ini (Taniguchi et al., 1994).

Sifat-sifat kuantitatif ikan seperti pertumbuhan, ketahanan terhadap perubahan lingkungan yang drastis dan ketahanan terhadap serangan bakteri patogen atau virus merupakan faktor penentu dalam keberhasilan budidaya ikan (Ferguson dan Lenore, 1990). Ikan bandeng merupakan ikan ekonomis penting selain untuk konsumsi juga unutuk penyediaan umpan hidup tuna, sehingga baik nener maupun gelondongannya harganya menjadi sangat mahal. Dengan keberhasilan Loka Penelitian Perikanan Pantai, dalam membenihkan dan membudidayakan ikan ini di tambak, produksi ikan bandeng dapat ditingkatkan walaupun belum memenuhi semua kebutuhan (Prijono et al., 1988, Prijono et al., 1992). Produksi dapat lebih ditingkatkan dengan usaha meningkatkan mutu induk dan benih. Sebagai tahap awal dari usaha perbaikan mutu genetik induk atau benih yaitu dengan mencari indikator seleksi. Dalam penelitian ini dilakukan pengamatan atau analisis hubungan antara gen esterase dengan pertumbuhan individu bandeng. Diharapkan dari hasil penelitian ini didapatkan indikator gen untuk seleksi pertumbuhan.

\section{BAHAN DAN METODE}

Nener ikan bandeng yang berasal dari alam dan panti benih masing-masing sebanyak 22.500 ekor, dipelihara terpisah pada tambak masing-masing seluas $1.500 \mathrm{~m}^{2}$. Pemeliharaan bandeng hanya dilakukan dengan pemupukan dasar tambak secara berkala (setiap 2 minggu) dengan pupuk TSP (10 ppm), urea (10 $\mathrm{ppm})$ dan kotoran ayam $(100 \mathrm{~kg} / \mathrm{Ha})$. Klekap dan organisme yang tumbuh di dasar tambak sebagai pakan utama nener peliharaan. Setelah dua bulan pemeliharaan, sebanyak masing-masing 200 ekor ikan dari kedua tambak tersebut diambil sampel secara acak.

Ikan sampel dimatikan menggunakan air es, kemudian dibawa ke laboratorium Lolitkanta-Gondol dalam keadaan dingin dengan es. Setibanya di Gondol bobot dan panjang ikan diukur, lalu disimpan dalam alat pembeku pada suhu $-20^{\circ} \mathrm{C}$, untuk selanjutnya dilakukan analisis variasi gen esterasenya (EST) dengan teknik elektroforesis. Organ hati ikan diambil dengan pisau lalu dimasukkan ke dalam tabung $1 \mathrm{ml}$, dipotong-potong dan diekstrak dengan larutan $0,005 \mathrm{M} \mathrm{KCN}$ dan $0,005 \mathrm{M} \mathrm{MgCL}_{2}$. Cairan enzim yang keluar diambil dengan kertas saring berukuran $1 \times 0,5 \mathrm{~cm}$.

Variasi gen esterase dianalisis dengan elektrophoresis gel tepung horizaontal. Gel dibuat dari tepung yang dihidrolisis (SIGMA) 12\% dengan campuran buffer Citric Acid Aminoprophylmorpholine (C-AMP) pada pH6. Kertas saring yang telah dibasahi dengan enzim diaplikasikan pada gel lalu dialiri listrik melalui elektroforesis dengan arus tetap $4 \mathrm{MA} / \mathrm{cm}^{2}$. Elektroforesis dilakukan pada suhu $5^{\circ} \mathrm{C}$ selama kurang lebih 4 jam, setelah itu diwarnai dengan zat pewarna yang spesifik untuk enzim esterase yaitu dengan $\alpha$ Naphthyl acetate, $\beta$ Naphtbyl 
acetate dan Fast Blue RR. Variasi gen yang diekspresikan dengan genotip dan alel akan tampak setelah 5 menit pewarnaan.

Berdasarkan hasil analisis sebelumnya (Sugama dan Haryanti, 1995) terdapat 6 genotipe pada lokus esterase atau tiga alel A, B dan C. Karena alel C sangat langka, maka tidak diikutkan dalam perhitungan untuk melihat hubungan bobot tubuh alel. Hanya genotipe AA, AB atau alel A dan B saja yang digunakan untuk analisis.

ANOVA satu arah dengan student $t$-test digunakan untuk menguji perbedaan bobot tubuh dengan genotip heterozigot dan homozigot (Sokal dan Rohlf, 1981).

\section{HASIL DAN PEMBAHASAN}

Zymogram genotip bandeng pada esterase lokus disajikan pada Figure 1 dan frekuensi alel dan frekuensi genotip serta ekspektasi Hardy-Weinberg disajikan pada Table 1. Dari uji heterogenitas dan dugaan frekuensi alel diuji dengan hukum Hardy-Weinberg tidak terlihat adanya perbedaan $(\mathrm{P}>0.05)$.

Dilihat dari hasil penyebaran genotip (Table $1 ; \mathrm{X}^{2}=0.37 ; \mathrm{X}^{2}=0.63$ ) tidak berbeda nyata $(P>0.01)$ dan sesuai dengan hukum Hardy-Weinberg. Hal ini menunjukan bahwa pembacaan genotip sesuai dengan ilmu turunan.

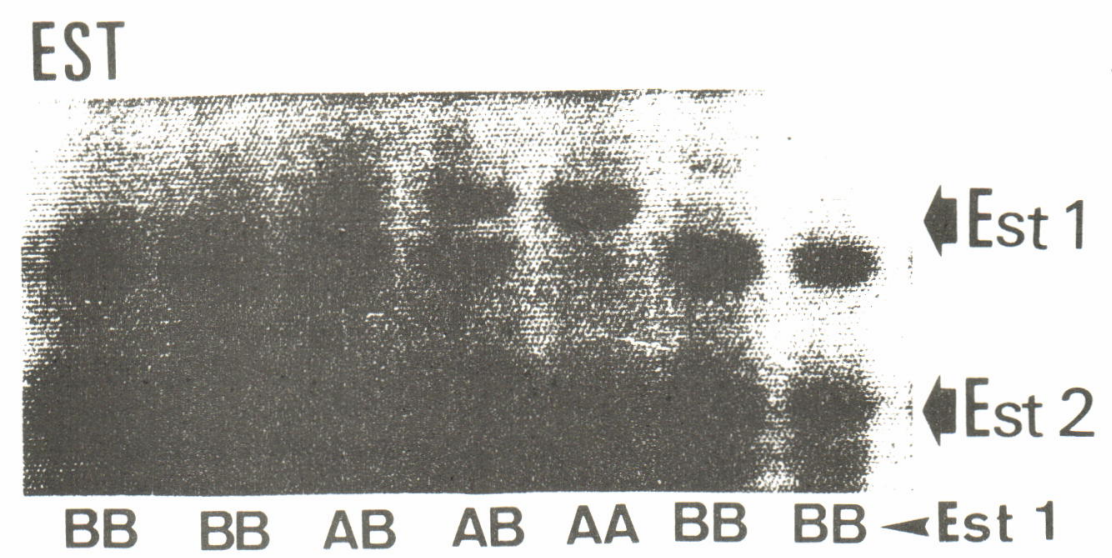

Figure 1. Genotype zymogram of Chanos chanos at esterase (EST) locus

Bobot tubuh ikan yang mempunyai genotip heterozigot dan homozigot untuk kedua sampel yang berasal dari alam dan panti benih juga dibandingkan. Hasil uji menunjukkan bahwa tidak terlihat perbedaan yang nyata dari bobot tubuh ikan yang heterozigot dengan ikan yang homozigot (Table 2). 
Table 1. Observed genotype frequencies, their Hardy-Weinberg expectation in parenthesis and allele frequency at Esterase EST-1 locus of milkfish Chanos chanos

\begin{tabular}{|c|c|c|c|c|c|c|c|c|c|c|}
\hline \multirow[b]{2}{*}{ Sample } & \multicolumn{4}{|c|}{ Genotype } & \multirow[b]{2}{*}{$B C$} & \multirow[b]{2}{*}{ CC } & \multicolumn{3}{|c|}{ Allelic Freq } & \multirow[b]{2}{*}{$X^{2}$} \\
\hline & $\boldsymbol{A A}$ & $A B$ & $A C$ & $B B$ & & & $\boldsymbol{A}$ & $\boldsymbol{B}$ & C & \\
\hline Natural & 30 & 91 & 1 & 76 & 2 & 0 & 0.380 & 0.613 & 0.007 & 0.37 \\
\hline Expected & $(28,9)$ & (93.2) & (2.7) & (75.2) & $(1.7)$ & $(0.00)$ & & & & \\
\hline Hatchery & 34 & 89 & 0 & 77 & 0 & 0 & 0.393 & 0.607 & 0 & 0.63 \\
\hline Expected & $(30.9)$ & (95.4) & 0 & 73.7 & 0 & 0 & & & & \\
\hline
\end{tabular}

Table 2. Mean dressed weight (g) of milkfish beterozygous and bomozygous in esterase locus

\begin{tabular}{lccrc}
\hline \hline Genotype & \multicolumn{5}{c}{ Sample } \\
\cline { 2 - 5 } & $N$ & Natural & $N$ & Hatchery \\
\hline Homozygous & 91 & $18.76 \pm 1.63$ & 101 & $18.05 \pm 1.54$ \\
Heterozygous & 106 & $18.93 \pm 1.84$ & 89 & $18.09 \pm 1.67$ \\
\hline F-value & 0.48 & 0.29 \\
\hline \hline
\end{tabular}

Perbandingan bobot tubuh ikan dengan genotip berbeda disajikan pada Table 3. Dari hasil uji terlihat bahwa individu ikan dengan genotip Esterase-1 AA (EST-1 AA) mempunyai bobot tubuh yang lebih besar dibandingkan dengan ikan yang mempunyai genotip EST-1 BB (Table 3). Namun individu yang mempunyai genotip EST-1 AB tidak berbeda bobot tubuhnya dengan ikan baik yang bergenotip EST-1 AA atau EST-1 BB. Dengan demikian terlihat adanya hubungan yang positif antara genotip dengan pertumbuhan pada EST-1 lokus, dalam hal ini ikan bandeng dengan genotip EST-AA cenderung tumbuh lebih cepat dibanding ikan bandeng dengan genotip BB, baik bandeng dari alam maupun dari panti benih. Di sini pengaruh lingkungan dapat diabaikan karena sampel yang dianalisis dipelihara dalam satu tambak di mana $\mathrm{Vp}=$ $\mathrm{Vg}+\mathrm{Ve}(\mathrm{Vp}=$ variasi fenotipik, $\mathrm{Vg}=$ variasi genotipik dan $\mathrm{Ve}=$ variasi lingkungan, nilainya nol karena dipelihara dalam satu tambak). 
Tabel 3. Mean dressed weight (g) of milkfish with genotype $A A, A B$ and $B B$ for EST-1 locus

\begin{tabular}{lcccc}
\hline \hline Genotype & $N$ & Natural $(g)$ & $N$ & Hatchery $(g)$ \\
\hline$A A$ & 30 & $19.12 \pm 1.85$ & 34 & $18.89 \pm 1.63$ \\
$A B$ & 91 & $18.75 \pm 1.43$ & 89 & $18.58 \pm 1.57$ \\
$B B$ & 76 & $17.03 \pm 1.98$ & 77 & $17.08 \pm 1.87$ \\
\hline F-value & \multicolumn{5}{c}{$3.45 *$} & $3.32 *$ \\
\hline \hline
\end{tabular}

Note: F value in significant level at $P<0.05$ is marked *

Adanya hubungan antara EST genotip dengan pertumbuhan juga didapat pada ikan kakap merah (Taniguchi et al., 1980). Selanjutnya dilaporkan oleh Sugama et al. (1990), bahwa dengan menyeleksi induk dengan genotip EST dapat meningkatkan laju pertumbuhan pada turunan berikutnya.

\section{KESIMPULAN}

Dari hasil penelitian ini dapat disimpulkan bahwa pertumbuhan individu ikan erat hubungannya dengan gen yang dikandung. Dalam penelitian ini, ikan bandeng dengan genotip EST-1 AA cenderung tumbuh lebih cepat. Dengan demikian lokus EST dapat dijadikan indikator seleksi untuk memperbaiki pertumbuhan ikan bandeng. Perlu diperhatikan bahwa ikan bandeng yang akan dilepas ke alam sebaiknya tidak dilakukan seleksi karena fungsi dari alel EST-1 BB belum diketahui dengan jelas.

\section{DAFTAR PUSTAKA}

Ferguson, M.M. and D.D. Lenore. 1990. Disease resistance and enzyme heterozygosity in rainbow trout, Heredity 64: 413417.

Prijono,A.,Tridjoko, I.N.A. Giri, A. Poernomo, W.E.Vanstone, C. Lim and T.Daulay. 1988. Natural spawning and larval rearing of milkfish in captivity in Indonesia Aquaculture $74: 127-130$.

Prijono, A., Z.I. Azwar, G. Sumiarsa, SN. Irianti dan T. Aslianti 1992 Pembenihan bandeng skala rumah tangga. Temu Karya Ilmiah Watabone. Feb. $199216 \mathrm{p}$.

Roed, K. H. 1986. Genetic variability in Norwegian wild reindeer. Heredity $104: 293-298$

Roed, K. H. 1987. Comparison of genetic variation in semi domestic and wild reindeer Heredity $105: 199-206$ 
Sugama, K., N. Taniguchi and S. Seki. 1992. Survival, growth and gonad development of Triploid red sea bream. Aquaculture and Fisheries Management, 23. 149-159.

Sugama, K. dan Haryanti. 1995. Variasi genetik ikan bandeng. Indonesia J. Fish Res (Inpress).

Taniguchi, N.,O. Okada and Y. Iyama 1980. Genetic study on biochemical polymorphism in red sea bream. Japan Fish Soc. 46: 437-443.

Taniguchi, N.,S. Seki and K. Murakami 1994. Triploidy in Ayu. Japan Fish Soc. $51: 503-511$.

Zhurkevich, M. and I. Komicheva 1986. Genetic polymorphism in serum reindeer. Genetic 12 : 56-65. 


\title{
UJI RESISTENSI BERBAGAI JENIS IKAN BUDIDAYA: LELE DUMBO, Clarias sp.; GURAME, Osphronemus goramy; MAS, Cyprinus carpio DAN NILA, Oreocbromis Niloticus TERHADAP INFEKSI CENDAWAN Apbanomyces sp.
}

\author{
Dayat Bastiawan"), Taukhid"), Mohamad Alifuddin ${ }^{* *}$ ) dan \\ Sri Nuryati*;
}

\section{ABSTRAK}

Uji resistensi berbagai jenis ikan budidaya yaitu Lele Dumbo (Clarias sp.), Gurame (Osphronemus goramy), Mas (Cyprinus carpio) dan Nila (Oreocbromis niloticus) terhadap infeksi cendawan Aphanomyces sp. telah dilakukan untuk mengetahui daya tahan jenis ikan budidaya tersebut.

Infeksi buatan dengan zoospora cendawan dilakukan dengan kepadatan $385 \mathrm{spora} / \mathrm{ml}$ dan untuk mempermudah terjadinya infeksi dibuatkan jalan masuk berupa goresan seluas $1 \mathrm{~cm}^{2}$ pada bagian punggung ikan. Setiap dua hari sekali diambil sampel sebanyak 10 ekor; lima ekor untuk reisolasi dan lima ekor untuk pemeriksaan histophatologis.

Hasil penelitian menunjukkan bahwa ikan lele dumbo merupakan ikan yang paling rentan terhadap infeksi cendawan Aphanomyces sp. dibandingkan dengan ikan mas, gurame dan nila.

ABSTRACT: Host Susceptibility of Apbanomyces sp. to Several Cultured Freshwater Fishes; Dumbo catfish (Clarias sp.), Giant gouramy (Ospbronemus goramy), Common carp (Cyprynus carpio), and Nile tilapia (Oreocbromis niloticus). By: Dayat Bastiawan, Taukbid, Mobamad Alifuddin, and Sri Nuryati.

The resistence of several cultured freshwater fishes; Dumbo catfish (Clarias sp.), giant gouramy (Osphronemus goramy), common carp (Cyprynus carpio), and nile tilapia, Oreochromis niloticus against the infection by Aphanomyces sp. was studied.

The fish were artificially infected by 385 spores/ $\mathrm{ml}$ through a $1 \mathrm{~cm} 2$ of abraded skin on the lateral area of the fish body. Ten fishes were sampled every two days after the infection for histophatological and reisolation studies.

Results of histological examination showed that 14 dumbo catfish were infected by Aphanomyces sp., other fishes were not infected. Reisolation of Aphanomyces sp., produced nine isolates from dumbo catfish and only one isolate from common carp.

KEYWORDS: Resistence test, fish culture, Clarias, Oreochromis

\section{PENDAHULUAN}

Epizootic Ulcerative Syndrome (EUS) merupakan salah satu penyakit yang banyak menyerang ikan-ikan budidaya maupun ikan-ikan liar. Secara visual

\footnotetext{
") Peneliti pada Balai Penelitian Perikanan Air Tawar, Sukamandi

**) Pengajar pada Fakultas Perikanan, IPB Bogor

*n+n) Mahasiswa Fakultas Perikanan, IPB Bogor
} 
penyakit ini ditandai dengan kerusakan bagian luar tubuh ikan yaitu luka-luka pada bagian kulit yang berkembang menjadi borok dan dapat berakhir dengan kematian (Lilley et al., 1992). Bastiawan dan Taukhid (1994) menjelaskan bahwa penyakit EUS yang banyak menyerang lele dumbo (Clarias sp.) di daerah Depok dan Sukabumi ternyata positif disebabkan oleh cendawan Aphanomyces. Cendawan tersebut diisolasi dari ulcer yang berwarna merah segar. Menurut Rukyani (1994), Aphanomyces diketahui telah menjadi penyebab penyakit EUS di Kalimantan Timur. Keberadaan cendawan ini dibuktikan melalui pemeriksaan histopatologi serta isolat yang didapatkan dari lele (Clarias sp.) dan gabus (Ophicephalus spp.) pada tahun 1984.

Aphanomyces astaci (Alifuddin, 1993) dikenal sebagai penyebab panyakit Aphanomycosis pada lobster air tawar dan crayfish. Tanda-tanda klinis Aphanomycosis adalah ikan yang terserang mengalami paralisa, terlihat diam terlentang di dasar kolam sampai mati dan tidak ada respon terhadap rangsangan eksternal yang diberikan. Infeksi umumnya terjadi di daerah persendian. Roberts et al. (1992) menyatakan bahwa ulcer pada tubuh ikan yang diperoleh dari beberapa kawasan di Asia Tenggara tidak menyerang target organ tertentu, tetapi ditemukan pada seluruh bagian tubuh ikan.

Aphanomycosis ternyata tidak hanya terjadi di Indonesia, tetapi juga di negara-negara lain. Pada tahun 1976, Mekenzie dan Hall telah berhasil mengisolasi cendawan dari ulcer (Red Spot Disease) pada ikan belanak (Mugil cephalus) dengan karakteristik: bercabang, tidak bersepta dan tidak mengandung pigmen dalam hifanya, dan setelah diidentifikasi ternyata cendawan tersebut diketahui dari kelompok Oomycetes (Lilley et al., 1992). Infeksi oleh cendawan Aphanomyces di Jepang ditemukan pada ikan Colisa lalia yang diimpor dari Singapura dan penyakit ini dapat meyebabkan mortalitas hingga $100 \%$. Cendawan Aphanomyces juga menjadi penyebab penyakit EUS di negaranegara Asia Tenggara (Robert et al., 1993).

Pada tahun 1982 Fraser et al.(1992) menemukan cendawan jenis serupa pada ikan Crayfish (Astacus astacus) yang terserang ulcer di Eropa. Sedangkan Subasinghe et al. (1990) menemukan tiga jenis cendawan: Aphanomyces sp., Achlya sp. dan Saprolegnia sp. dari ikan yang terserang penyakit ulcer di Srilanka.

Untuk mengetahui ketahanan berbagai jenis ikan terhadap serangan cendawan Aphanomyces ini maka dilakukan penelitian, untuk mengetahui jenis ikan yang tahan terhadap serangan Aphanomyces pada saat terjadi wabah penyakit EUS. Tujuan penelitian adalah untuk mengetahui ketahanan/ resistensi berbagai jenis ikan budidaya air tawar, yaitu lele dumbo (Clarias sp.) gurame (Osphronemus goramy), mas (Cyprinus carpio) dan nila (Oreochromis niloticus) terhadap infeksi cendawan Aphanomyces sp. 


\section{BAHAN DAN METODE}

Tangki serat kaca dicuci dengan sabun sampai bersih, direndam dengan air garam dan diendapkan selama semalam. Tangki diisi air sebanyak 240 liter dan setelah itu dipasang aerasi.

Kultur cendawan Aphanomyces sp. yang digunakan untuk menghasilkan zoospora dilakukan pada media GYA (Glucose Yeast Agar) dan GY cair (Glucose Yeast-tanpa agar). Hifa cendawan dari kultur murni diletakkan dalam kotak plastik berlubang dan dimasukkan ke dalam tangki serat kaca yang sudah diisi air dan ikan yang telah dilukai. Selanjutnya tangki serat kaca ditutup dengan menggunakan papan plastik yang bergelombang. Kepadatan spora yang digunakan adalah $385 \mathrm{sel} / \mathrm{ml}$.

Ikan lele dumbo, gurame, mas dan nila masing-masing sebanyak 70 ekor dengan ukuran antara $10-15 \mathrm{~cm}$, dilukai dengan cara mengerok pada bagian sisi tubuhnya. Pengerokan pada ikan lele dilakukan dengan cara menghilangkan lendir yang selanjutnya dikerok sampai luka, sedang untuk ikan mas, gurame dan nila dicabut sisiknya. Ukuran luka kira-kira $1 \mathrm{~cm}^{2}$. Maksud pengerokan adalah untuk menimbulkan luka yang dapat menjadi jalan bagi masuknya spora Aphanomyces sp. Dua hari setelah inokulasi dilakukan sampling yaitu dengan cara mengambil 10 ekor ikan untuk tiap-tiap jenis secara acak. Lima ekor digunakan untuk bahan isolasi dan lima ekor yang lain untuk histopatologi, yaitu untuk konfirmasi adanya hifa dalam jaringan. Sampling dilakukan setiap 2 hari sekali sebanyak 4 kali selama masa penelitian.

Untuk memastikan ada tidaknya cendawan yang menginfeksi ikan sampel dilakukan reisolasi dari luka yang terjadi, dan selanjutnya isolat cendawan diidentifikasi. Sebagai konfirmasi hasil re-isolasi maka dari jaringan histologi diamati kemungkinan adanya sel granuloma pada jaringan otot ikan sampel.

\section{HASIL DAN PEMBAHASAN}

\section{Hasil Pengamatan Secara Makroskopis}

Pengamatan secara makroskopis menunjukkan bahwa ikan-ikan yang telah diinfeksi dengan cendawan Apbanomyces sp. terlihat gelisah dan berenang tanpa arah. Luka-luka pada lele dumbo semakin lama semakin lebar dan dalam. Luka tersebut umumnya berwarna merah segar atau merah pucat.

Tizard (1982) menyatakan bahwa hewan mempunyai mekanisme pertahanan di dalam tubuh, akan tetapi mikroorganisme pertama kali harus menghadapi sistem pertahanan tersebut pada permukaan hewan. Sistem proteksi pada permukaan dicapai melalui mekanisme fisik dan kimiawi lingkungan.

Apabila terjadi luka atau invasi patogen ke dalam tubuh maka organisme yang bersangkutan akan mengadakan respon inflamasi jaringan. Respon inflamasi akut ditandai dengan adanya rasa sakit, bengkak, kemerah-merahan 
dan panas (Anderson, 1974). Menurut Ward (1978) tanda-tanda inflamasi akut adalah dengan bertambah lebarnya pembuluh darah dan munculnya sel-sel darah putih, sedang inflamasi kronis ditandai dengan terbentuknya sel-sel granuloma. Sel-sel ini terbentuk karena adanya benda asing dalam tubuh dan terjadi infeksi oleh cendawan.

Luka pada ikan gurame yang terinfeksi berwarna kemerah-merahan dan pucat kekuningan. Pada pengambilan sampel yang ke dua ditemukan ikan yang pada bagian tepi lukanya terdapat selaput berwarna putih.

Kondisi eksternal ikan mas ditandai dengan luka yang berwarna kemerahan. Warna merah makin menghilang, luka menyempit yang ditandai dengan munculnya selaput putih di sekeliling luka.

Hampir sama dengan ikan mas, luka pada ikan nila berwarna kemerahan dan sekelilingnya berselaput putih. Semakin lama luka berwarna bening dan menyempit.

Pada hari pertama infeksi, luka pada ikan lele tampak berwarna kemerahan. Hal ini menunjukkan bahwa ikan lele tersebut mengalami inflamasi yang merupakan sistem pertahanan ikan dalam melawan benda/organisme asing yang menyerang dirinya. Pada hari kedua terlihat bahwa ikan uji mengalami inflamasi yang semakin parah dengan gejala berenang tidak tentu arah, kadangkadang berada dalam posisi vertikal dengan kepala di bagian atas. Keadaan ini merupakan gejala bahwa ikan tersebut mengalami rasa sakit. Menurut Anderson (1974), tanda-tanda inflamasi akut di antaranya adalah timbul warna kemerah-merahan dan rasa sakit. Warna kemerah-merahan disebabkan karena pembuluh darah yang melebar (Ward, 1978) serta kondisi luka dalam keadaan yang terbuka.

Luka berwarna kemerahan ini tidak hanya terdapat pada ikan lele, tetapi juga pada ketiga jenis ikan lain. Ini merupakan fenomena yang wajar dari suatu organisme yang mempunyai mekanisme pertahanan di dalam tubuhnya untuk menghadapi serangan patogen (Tizard, 1982). Perbedaan ikan lele dengan ketiga jenis ikan lain adalah warna luka pada ikan lele semakin lama semakin berwarna merah segar dan luka semakin dalam. Sedang pada ketiga jenis ikan yang lain, luka yang semula berwarna merah cerah (sepintas hampir sulit dibedakan dengan warna luka pada ikan lele) semakin lama semakin memudar, cenderung pucat dan bening. Pada pinggir luka terdapat selaput putih semakin lama semakin lebar dan luka semakin menyempit.

Menyempitnya luka oleh lapisan epidermis, menurut Ward (1978) disebabkan karena sel-sel darah putih sudah bekerja dalam menyusun sistem pertahanan. Pada ikan gurame, ikan mas dan ikan nila yang lukanya semakin lama semakin menyempit, hal ini menandakan bahwa sel-sel darah putih ikan berada dalam jumlah yang cukup sehingga dapat mengatasi terjadinya luka. Bahanbahan asing (agen penyakit) dari luar yang masuk ke dalam tubuh ikan pertama kali menyerang bagian luar tubuh. Dalam keadaan normal, agen penyakit 
yang menyerang ikan akan berhadapan dengan sel-sel mucus. Sel-sel ini berfungsi untuk mengumpulkan dan membuang agen penyakit tersebut.

\section{Hasil Pengamatan Secara Mikroskopis}

Pengamatan secara mikroskopis yaitu dengan cara mengamati preparat histologi dilakukan untuk mengetahui ada tidaknya sel-sel granuloma (Tabel 1).

Table 1. Hysthological observation on the presence of granulomma cells

\begin{tabular}{|c|c|c|c|c|}
\hline \multirow[t]{2}{*}{$\overline{\text { Sampling }}$} & \multirow{2}{*}{$\begin{array}{l}\text { Catfish } \\
12345\end{array}$} & Gouramy & Carp & Nile tilapia \\
\hline & & 12345 & 12345 & 12345 \\
\hline$I$ & ++++- & 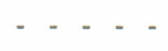 & $-\ldots$ & $\cdots$ \\
\hline II & $-\cdots$ & $-\ldots$ & $-\ldots$ & $-\cdots$ \\
\hline III & +++++ & $\ldots$ & $\ldots$ & $\cdots$ \\
\hline$I V$ & +++++ & $\ldots$ & $\ldots$ & $\ldots$ \\
\hline
\end{tabular}

Note: $+\quad=$ Granuloma EUS

= No granuloma

Melalui pemeriksaan histopatologi, dari 20 ekor ikan uji untuk tiap-tiap jenis diperoleh hasil bahwa ikan lele positif terinfeksi oleh cendawan Aphanomyces sp. sebanyak 14 ekor. Ikan gurame, mas dan nila tidak terinfeksi oleh cendawan Aphanomyces sp. karena tidak ditemukan adanya sel-sel granuloma pada jaringan otot yang diperiksa.

Indikator spesifik bahwa ikan uji positif terinfeksi oleh cendawan Aphanomyces sp. adalah dengan ditemukannya sel-sel granuloma yang merupakan pelindung terhadap bahan-bahan asing terutama hifa yang menyerang jaringan otot. Hatai et al. (1994) juga menemukan sel-sel granuloma pada ikan Colisa lalia dan ikan ayu yang terinfeksi cendawan Aphanomyces sp. Sel-sel granuloma mengelilingi hifa yang terdapat dalam jaringan. Dalam potongan melintang hifa berbentuk bulat. Dengan adanya sel-sel granuloma sudah dapat dipastikan bahwa ikan tersebut terinfeksi cendawan Aphanomyces sp.

Adanya sel-sel granuloma menunjukkan bahwa ikan tersebut mengalami inflamasi kronis (Ward, 1978). Apabila ikan yang diinfeksi belum mengalami granulomatosis berarti ikan tersebut mengadakan perlawanan dengan mekanisme yang tidak terlalu berat, yaitu ditandai dengan munculnya warna kemerah-merahan, rasa sakit, dan lain sebagainya. Bila pada ikan ditemukan sel-sel granuloma berarti serangan cendawan Aphanomyces sp. masih dapat berkelanjutan dan kondisi ikan semakin parah. Bila mekanisme pertahanan 
ikan tidak mampu mengatasi serangan cendawan Aphanomyces sp. maka penyakit EUS akan semakin parah dan dapat berakhir dengan kematian.

Pemeriksaan histopatologi terhadap jaringan otot ikan lele dumbo menunjukkan adanya sel-sel granuloma, sedang pada ikan mas tidak ditemukan. Hal ini dapat terjadi karena zoospora yang diinfeksikan pada ikan mas masih belum menembus jaringan otot yang lebih dalam. Diduga, mekanisme pertahanan tubuh ikan mas pada waktu tersebut belum bekerja secara sempurna, sehingga infektan yang masuk ke dalam tubuh belum dapat dihancurkan. Terbukti dengan diperolehnya isolat pada sampling pertama (48 jam setelah infeksi).

Setelah dilakukan isolasi terhadap luka pada ikan yang diinfeksi cendawan Aphanomyces sp. diperoleh 9 isolat cendawan yang bersifat parasitik. Hasil selengkapnya dapat dilihat pada Table 2.

Table 2. Re-isolation of Aphanomyces sp. from four freshwater fish species

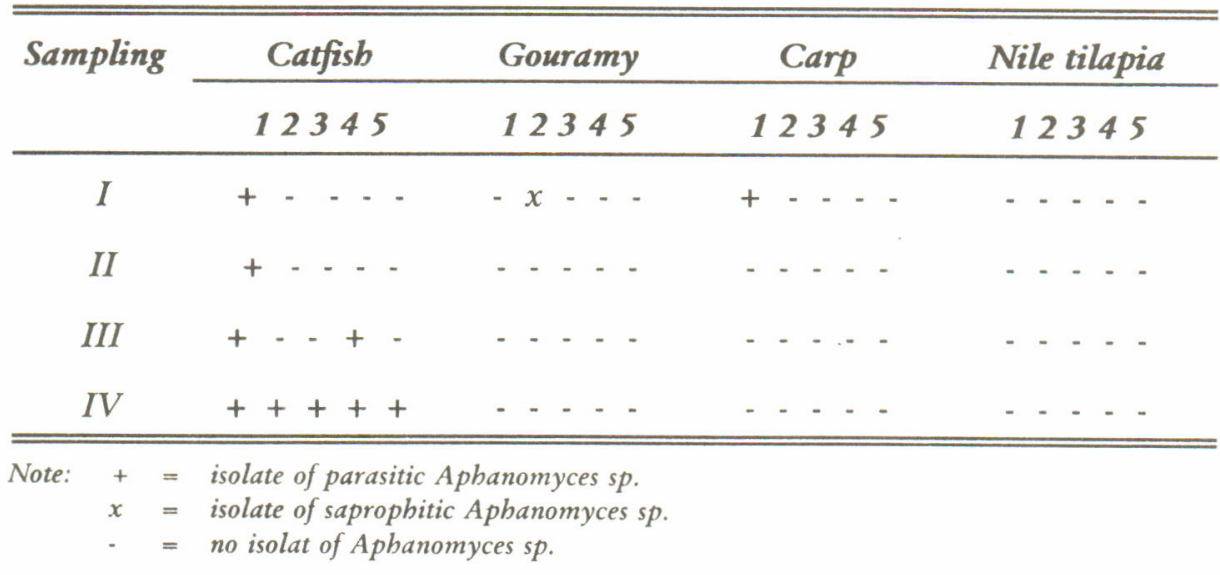

Cendawan yang didapatkan dari isolasi bersifat parasitik, yaitu 9 isolat dari ikan lele dan satu isolat dari ikan mas. Satu isolat didapatkan dari ikan gurame dan bersifat saprofitik. Isolat Aphanomyces sp. yang diperoleh dari ikan lele dumbo dan ikan mas bersifat parasitik. Cendawan yang bersifat parasitik mempunyai sistem percabangan menyamping dengan bola spora sebanyak 3-4 buah. Isolat tersebut dapat menguraikan protein pada media GYSMA karena menghasilkan enzim proteolitik, terbukti dengan terdapatnya daerah bening di sekeliling koloni. Ini menandakan bahwa isolat tersebut mampu menguraikan protein pada inangnya, yaitu lele dumbo. Roberts et al. (1992) menyatakan bahwa salah satu ciri Aphanomyces sp. parasitik adalah menghasilkan cluster (bola) spora lebih dari satu dan keluar dari (samping) hifa, sedangkan Aphanomyces sp. yang bersifat saprofitik hanya menghasilkan satu cluster (bola) spora dan keluar dari bagian terminal (ujung hifa). Reisolasi yang dilakukan 
terhadap jaringan otot di bawah luka pada ikan gurame menghasilkan isolat cendawan Aphanomyces sp. yang bersifat saprofitik. Ciri-ciri cendawan saprofitik adalah terdapatnya satu kantung spora pada bagian terminal hifa cendawan (Willoughby, 1994). Setelah ditanam pada media GYSMA, isolat tidak menunjukkan reaksi positif, yang artinya cendawan tidak menghasilkan enzim proteolitik. Keadaan tersebut ditandai dengan tidak adanya daerah bening di sekeliling koloni. Terdapatnya cendawan Aphanomyces sp yang bersifat saprofitik ini disebabkan karena media ikan tercemar pada waktu penginfeksian.

Cendawan Aphanomyces sp. termasuk dalam filum Phycomycetes, kelas Oomycetes, ordo Saprolegniales, famili Saprolegniaceae, genus Aphanomyces (Alifuddin, 1993). Dalam famili Saprolegniaceae ini terhimpun cendawan yang kebanyakan berasosiasi dengan penyakit pada ikan maupun kerang-kerangan. Genus-genus yang tergabung dalam famili ini adalah Saprolegnia, Acblya, dan Aphanomyces (Willoughby, 1994).

Anderson (1974) menyatakan bahwa pembentukan kista Aphanomyces terjadi di mulut zoosporangium. Aphanomyces memiliki hifa yang halus dan zoospora yang khas yang terjadi di jajaran tunggal di dalam sporangium.

Reproduksi cendawan Aphanomyces dilakukan secara seksual maupun aseksual, zoosporangium dibentuk dari spora vegetatif dan zoospora berkembang secara apikal dengan bentuk memanjang (Alifuddin, 1993). Biasanya reproduksi aseksual pada Aphanomyces terhenti namun kejadian ini termasuk jarang. Bersamaan dengan pembentukan spora, organ reproduksi seksual kelihatan seperti filamen vegetatif. Namun pembentukan organ seksual ini mungkin terjadi apabila berada pada organisme dengan lapisan kulit yang cocok dan dipelihara pada kondisi yang terkontrol.

Menurut Willoughby (1994), Aphanomyces akan berkembang membentuk spora dan membebaskan zoospora setelah kira-kira 5 hari. Pada famili Saprolegniaceae, sporangia yang berisi spora aseksual (zoospora) membebaskan zoospora yang mempunyai 2 flagela, di mana zoospora ini merupakan zoospora primer. Zoospora ini tidak menginfeksi ikan karena umur keaktifannya hanya beberapa menit dan akhirnya membentuk kista. Tidak lama kemudian zoospora motil dilepaskan dan zoospora ini merupakan zoospora sekunder yang lebih aktif dan umur keaktifannya lebih lama dibanding zoospora primer. Zoospora primer pada Acblya dan Aphanomyces beristirahat dan membentuk bola di mulut sporangium. Beda antara Achlya dan Aphanomyces ini terletak pada ukuran sporangium di mana sporangium Achlya lebih lebar ukurannya dibanding sporangium Aphanomyces.

Pertumbuhan zoospora menjadi tunas tampaknya terjadi sebagai respon ketika menyentuh substrat yang cocok. Cendawan ini tidak mempunyai alat khusus untuk melekatkan diri pada substrat, akan tetapi tunas yang muncul 
dari zoospora yang sedang bertunas menembus epikutikula melalui aksi penguraian lemak (lypolitic). Kemampuan menguraikan lemak tampaknya hanya dimiliki oleh tunas yang muncul dari zoospora, sedang hifa mempunyai kemampuan untuk menguraikan kitin (Nyhlen dan Unestam, dalam Johnson, 1979).

Sebaliknya pada ikan nila, dengan pemeriksaan histopatologi tidak ditemukan sel-sel granuloma dan melalui reisolasi cendawan tidak didapatkan isolat Aphanomyces. Dari kondisi lukanya sendiri tidak begitu parah, yaitu mengalami inflamasi yang ditandai dengan munculnya warna merah yang bertahan hanya sampai sampling ke dua. Setelah itu luka cenderung membaik. Dari fenomena di atas dapat diketahui bahwa ikan yang paling rentan terhadap infeksi cendawan Aphanomyces sp. adalah ikan lele dumbo, sekaligus mempertegas bahwa ikan ini merupakan inang spesifik bagi cendawan Aphanomyces sp.

\section{KESIMPULAN DAN SARAN}

Dari hasil penelitian di atas dapat disimpulkan bahwa ikan lele merupakan ikan yang paling rentan terhadap cendawan Apbanomyces sp. dibandingkan ikan lainnya.

\section{UCAPAN TERIMA KASIH}

Dalam kesempatan ini penulis mengucapkan banyak terima kasih kepada Sdr. Bambang Priyadi dan Sdr. Komar yang telah membantu dalam pelaksanaan penelitian dan penyiapan histhopath, sehingga penelitian ini berjalan dengan lancar. Penelitian ini dibiayai oleh dana Proyek ACIAR (No. Project: 9130).

\section{DAFTAR PUSTAKA}

Alifuddin, M. 1993. Penyakit Mikotik Ikan. Fakultas Perikanan-IPB. Bogor. 50 hal.

Anderson, D.P. 1974. Fish Immunology. T.F.H. Publications Inc. Ltd. USA. $273 \mathrm{p}$.

Bastiawan, D. dan Taukhid. 1995. Status dan Pathogenitas Aphanomyces sp. (Oomycetes) dalam Penyakit Epizootic Ulcerative Syndrome (EUS) pada Ikan Lele Dumbo (Clarias gariepinus). Kumpulan Makalah Lengkap, Kongres Nasional Perhimpunan Mikologi Kedokteran Manusia dan Hewan I dan Temu Ilmiah 21-24 Juli 1994. Balai Penerbit Fakultas Kedokteran Universitas Indonesia. Hal 208-219. 
Fraser, C.G., R.B.Callinan and L.M.Calder. 1992. Aphanomyces Species Associated With Red Spot Disease: An Ulcerative Disease of Estuarine Fish From Eastern Australia. Jornal of Fish Disease, 15: 173-181.

Hatai, K., N.Nakamura, S.A.Rha, K.Yuasa and S.Wada. 1994. Aphanomyces Infection in Dwarf Gourame (Colisa lalia). Fish Pathology 29: 95-99.

Johnson, P.T. 1979. Pathogen: Viral, Ricketsial, Bacterial, Fungal in Anthony J. Provenzano (ed.). Pathobiology 6.

Lilley, J.H., M.J.Phillips and K.Tonguthai. 1992. A Review of Epizootic Ulcerative Syndrome (EUS) in Asia. Aquatic Animal Health Research Institute - Kasetsart University Campus. Bangkok. 73 p.

Roberts, R.J., G.N.Frerichs and S.D.Millar. 1992. Epizootic Ulcerative Syndrome - The Current Position. Asian Aquaculture I. Editors: M.Shariff, R.P.Subasinghe and J.R.Arthur. Fish Health Section, Asian Fisheries Society. Manila. p. 431-436.

Robert, R.J., L.G.Willoughby and S.Chinabut. 1993. Mycotic Aspects of Ulcerative Syndrome (EUS) at Asian Fishes. Journal of Fishes Diseases, 16 169-183.

Rukyani, A. 1994. Status of Epizootic Ulcerative Disease in Indonesia. Research Instistute of Freshwater Fisheriees. Bogor. 12 p.

Subasinghe, R.P., L.P.Jayasinghe, K.S.W.Balasuriya, and M.Kulathilake. 1990. Preliminary investigations into the bacterial and fungal pathogens associated with the ulcerative fish disease syndrome in Sri Langka. Hirano, R. and I.Hanyu (Eds.). Proceeding of the Second Asian Fisheries Forum, 17-22 April 1990. Tokyo, Japan. Asian Fisheries Society, Manila, Philippines. p.655-657.

Tizard, I. 1982. Pengantar Immunobiology Veteriner. W.B.Sounders Company. Philadelphia-London-Toronto-Mexico City-Rio de Jeneiro-Sydney-Tokyo. 497 hal.

Ward, P.A. 1978. Mechanisms of Tissue Injury: Inflammation in J.A.Bellanti. Immunology II. W.B.Saunders Company. Philadelphia-London-Toronto and Igaku Shoin LTD Tokyo. 874 hal.

Willoughby, L.G. 1994. Fungi and Fish Diseases. Pisces Press. Stirling. 57 p. 